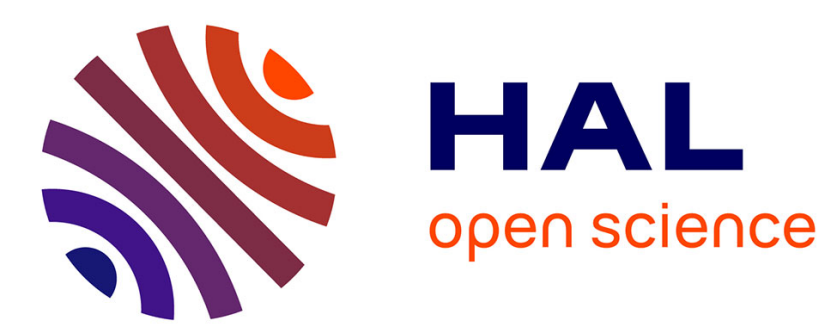

\title{
Atmospheric Fate and Impact of Perfluorinated Butanone and Pentanone
}

Yangang Ren, François Bernard, Véronique Daële, Abdelwahid S Mellouki

\section{To cite this version:}

Yangang Ren, François Bernard, Véronique Daële, Abdelwahid S Mellouki. Atmospheric Fate and Impact of Perfluorinated Butanone and Pentanone. Environmental Science and Technology, 2019, 53 (15), pp.8862-8871. 10.1021/acs.est.9b02974 . insu-02262364

\section{HAL Id: insu-02262364 https://hal-insu.archives-ouvertes.fr/insu-02262364}

Submitted on 2 Aug 2019

HAL is a multi-disciplinary open access archive for the deposit and dissemination of scientific research documents, whether they are published or not. The documents may come from teaching and research institutions in France or abroad, or from public or private research centers.
L'archive ouverte pluridisciplinaire $\mathbf{H A L}$, est destinée au dépôt et à la diffusion de documents scientifiques de niveau recherche, publiés ou non, émanant des établissements d'enseignement et de recherche français ou étrangers, des laboratoires publics ou privés. 
6

7

9

10

11

12 Corresponding author

13 *mellouki@cnrs-orleans.fr

\section{Affiliations}

15

16

Journal: Environmental Science and Technology

\section{butanone and pentanone \\ Atmospheric fate and impact of perfluorinated}

Yangang Ren, François Bernard, Véronique Daële, Abdelwahid Mellouki*

Institut de Combustion Aérothermique, Réactivité et Environnement, Centre National de la Recherche Scientifique (ICARE-CNRS), Observatoire des Sciences de l'Univers en région Centre (OSUC), CS 50060, 45071 cedex02, Orléans, France 4 .

16 


\section{Abstract}

Perfluoroketones, used as replacement to halons and CFCs, are excluded from the Montreal Protocol because they are considered as non-ozone depleting substances. However, their chemical structure makes them possible greenhouse gases if their atmospheric lifetimes are long enough. To assess that possibility, we investigated the photolysis of perfluoro-2-methyl-3-pentanone (PF-2M3P), and perfluoro-3-methyl-2butanone (PF-3M2B) using outdoor atmospheric simulation chambers. In addition, the photolysis of a non fluorinated pentanone (2-methyl-3-pentanone, 2M3P) was studied. The results showed that photolysis is the dominant loss pathway of PF-2M3P and PF$3 \mathrm{M} 2 \mathrm{~B}$ in the troposphere whereas $2 \mathrm{M} 3 \mathrm{P}$ is lost by both photolysis and gas phase reaction with atmospheric oxidants. The photolysis effective quantum yields of PF2M3P, PF-3M2B and 2M3P were estimated and some of the main products identified. The photolysis of PF-2M3P and PF-3M2B was found to have a minor impact on the atmospheric burden of fluorinated acids. The atmospheric lifetimes of PF-2M3P, PF3M2B and 2M3P were estimated to 3-11 days, 13 days and 1-2 days, respectively. Combining the obtained data, it has been concluded that with 100-year time horizon global warming potentials $\left(\mathrm{GWP}_{100}\right)$ equivalent to $<0.21, \sim 0.29$ and $\leq 1.3 \times 10^{-7}$ for PF2M3P, PF-3M2B and 2M3P, respectively, these compounds will have a negligible impact on global warming.

Keywords: perfluorinated ketones, UV absorption spectrum, IR absorption spectrum, photolysis rates, natural irradiation, atmospheric lifetime, global warming potential. 
$39 \quad$ TOC art

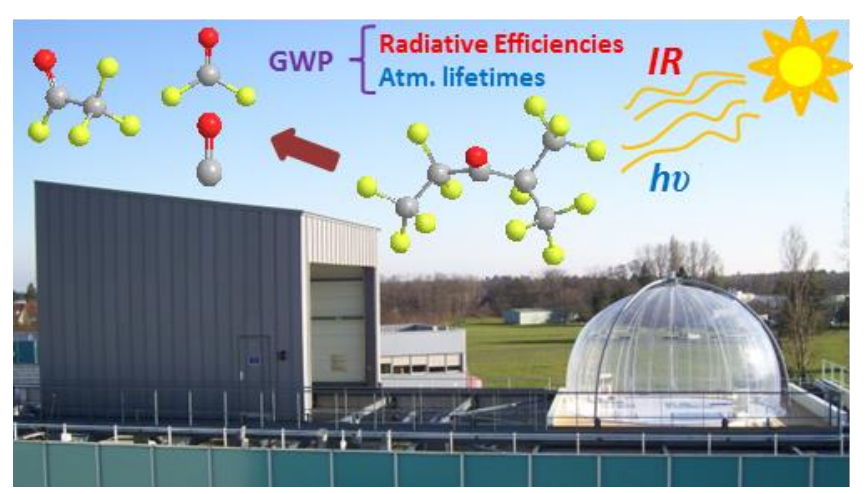




\section{Introduction}

Along with hydrofluorocarbons (HFCs), perfluorocarbons (PFCs) are non-ozone depleting substances and therefore excluded from the Montreal Protocol. ${ }^{1}$ However, they are considered as greenhouse gases due to their strong absorption in the infrared spectral region in the atmospheric window combined to their long atmospheric lifetimes. ${ }^{2}$ Their atmospheric concentrations have been growing rapidly over last decades and potentially continue to grow. ${ }^{3}$ They have been widely used for the cooling of power electronics over the last decade. Perfluoroketones such as perfluoro-2-methyl3-pentanone (PF-2M3P, $\mathrm{C}_{2} \mathrm{~F}_{5} \mathrm{C}(\mathrm{O}) \mathrm{CF}\left(\mathrm{CF}_{3}\right)_{2}$, Novec 649/1230) and perfluoro-3methyl-2-butanone (PF-3M2B, $\mathrm{C}_{2} \mathrm{~F} 5 \mathrm{C}(\mathrm{O}) \mathrm{CF}\left(\mathrm{CF}_{3}\right)_{2}$, Novec5110) are among the

51 important replacement chemicals to halons and CFCs ${ }^{4-5}$. PF-2M3P and PF-3M2B are

52 advanced heat transfer perfluorocarbons with high dielectric strength. Up to $30 \mathrm{t}$ of PF-

53 2M3P could be released into the atmosphere each year from fire-protection systems ${ }^{6}$.

54 PF-3M2B is being used as versatile insulating gas for medium and high voltage 55 applications including gas insulated lines, gas insulated switchgear and circuit 56 breakers. $^{7}$ The large production and usage of both chemicals are likely to induce their 57 direct emission into the atmosphere.

59 Similarly to other volatile organic compounds, PF-2M3P and PF-3M2B may be 60 potentially removed from the atmosphere through photolysis, gas phase chemical 61 reactions with the main atmospheric oxidants, hydrolysis and deposition. The 
atmospheric fate of PF-2M3P has been subject to a limited number of investigations.

63 Photolysis studies were based on the use of artificial and natural irradiations. ${ }^{5,89}$ The

64 atmospheric lifetime of PF-2M3P has been found to be controlled by photolysis and

65 reported to be in the range of 4-14 days depending on latitude and period of the year. ${ }^{6}$

66 The gas phase reactions with $\mathrm{OH}$ radical and ozone as well as hydrolysis represent

67 minor contribution to the total removal of PF-2M3P from the atmosphere. ${ }^{5-6}$ To the

68 best of our knowledge, no experimental data on the photolysis of PF-3M2B have been

69 reported. Hence, the present work aims at investigating the photolysis of PF-3M2B

70 under atmospheric conditions and improving the existing data on PF-2M2B in order to

71 evaluate their atmospheric impacts. In addition to the two perfluorinated ketones, a non-

72 fluorinated analogue aliphatic ketone to PF-2M3P, 2-Methyl-3-pentanone (2M3P,

$\left.73 \mathrm{C}_{2} \mathrm{H}_{5} \mathrm{C}(\mathrm{O}) \mathrm{CH}\left(\mathrm{CH}_{3}\right)_{2}\right)$ has been investigated. The UV-Visible and infrared (IR)

74 absorption spectra of PF-2M3P, PF-3M2B and 2M3P were measured. Their photolysis

75 rates were determined using two complementary atmospheric simulation chambers

76 with natural sunlight irradiation. Atmospheric lifetimes and global warming potentials

77 (GWP) for the three studied compounds are reported and discussed in terms of their

78 atmospheric impacts.

\section{Experimental Section}

81 2.1. UV absorption spectra 
83 briefly presented here. The UV-Visible absorption spectra of PF-2M3P, PF-3M2B, and $842 \mathrm{M} 3 \mathrm{P}$ were measured using a spectrophotometer equipped with a 1200 grooves $\mathrm{mm}^{-1}$ 85 grating and a charge-coupled device (CCD) camera. The collimated output of a $30 \mathrm{~W}$ 86 deuterium lamp passed through a $100 \mathrm{~cm}$ long and $2.5 \mathrm{~cm}$ diameter Pyrex absorption cell equipped with quartz windows and focused onto the entrance slit of the spectrometer. Measurements were made over the wavelength region $220-400 \mathrm{~nm}$ by recording typically three overlapping regions of about $15 \mathrm{~nm}$. Typically, each measurement consisted of 8-13 scans of diode array. The wavelength scale was

91 calibrated using the emission lines from a low-pressure $\mathrm{Hg}$ pen ray lamps $(253.7,313.2$, and $365 \mathrm{~nm}$ ). Absorption cross sections, $\sigma(\lambda)$ (in $\mathrm{cm}^{2}$ molecule ${ }^{-1}$ ) were obtained using 93 the Beer's law:

$$
\sigma(\lambda)=\frac{-\ln \left[I(\lambda) / I_{0}(\lambda)\right]}{C L}
$$
Eq. 1 where $L$ is the path length of absorption cell (in $\mathrm{cm}$ ), and $C$ is the concentration of the studied compound (in molecule $\mathrm{cm}^{-3}$ ). $\mathrm{I}_{0}(\lambda)$ and $\mathrm{I}(\lambda)$ are the light intensities in the absence and in the presence of the compound in the absorption cell, respectively. The concentration of the species of interest in the absorption cell was obtained from the measured pressure using a 0-10 Torr capacitance manometer. Measurements of the PF2M3P, PF-3M2B and 2M3P UV absorption spectra were performed at T $=(292 \pm 1) \mathrm{K}$

101 using the concentration ranges $[\mathrm{PF}-2 \mathrm{M} 3 \mathrm{P}]=(0.29-2.7) \times 10^{17},[\mathrm{PF}-3 \mathrm{M} 2 \mathrm{~B}]=(0.27-$ 102 $3.0) \times 10^{17}$ and $[2 \mathrm{M} 3 \mathrm{P}]=(0.43-2.9) \times 10^{17}$ molecule $\mathrm{cm}^{-3}$. 


\subsection{Atmospheric simulation chambers}

107 investigated in a $3.4 \mathrm{~m}^{3}$ Teflon outdoor chamber. Both HELIOS and the $3.4 \mathrm{~m}^{3}$ Teflon

108 outdoor chambers allowed photolysis experiments to be performed under natural solar 109 exposure.

\section{$111 \quad$ 2.2.1. HELIOS}

112 The facility consists of a $90 \mathrm{~m}^{3}$ hemispherical outdoor simulation chamber

$113\left(47^{\circ} 50^{\prime} 18.39 \mathrm{~N} ; 1^{\circ} 56^{\prime} 40.03 \mathrm{E}\right)$ made of FEP Teflon film. This facility has been

114 described previously. ${ }^{9}$ The light transmission ranges from 88 to $95 \%$ over the entire

115 solar spectrum. Two fans installed in the chamber ensure a rapid mixing of reactants

116 (within less than 90 seconds). Solar actinic flux (290-660 nm) and photolysis

117 frequencies of $\mathrm{H}_{2} \mathrm{O}_{2}, \mathrm{HONO}, \mathrm{HCHO}, \mathrm{NO}_{3}, \mathrm{NO}_{2}$ and $\mathrm{O}\left({ }^{1} \mathrm{D}\right)$ were measured by a

118 spectroradiometer (Meteorologie Consult GmbH 6007). Pressure, relative humidity and

119 temperature were continuously monitored by a three-axis Ultrasonic Anemometer

120 (Delta Ohm, HD 2003) installed in the center of the chamber. The temperature

121 distribution was also measured using six thermocouples (PT-100) spatially and equally

122 distributed inside the chamber. A mobile protective housing kept the chamber under

123 the dark and can be easily moved to fully expose the chamber to sunlight within 30 
124 seconds. The experimental duration under irradiation was between 3 and 7 hours, in

125 which the temperature typically increased by $\sim 10{ }^{\circ} \mathrm{C}$. Between experiments, the 126 chamber was cleaned by flushing pure air through for at least 12 hours.

127 Organic compounds were monitored via in situ Fourier transform infrared 128 spectrometry (FT-IR, Bruker Vertex70 spectrometer) coupled to a White-type 129 multipass cell (302.6 m optical path length). Infrared spectra were recorded every 3 130 minutes by co-adding 250 interferograms with a resolution of $0.4 \mathrm{~cm}^{-1}$. The gas phase 131 mixture was also analyzed using a gas chromatography coupled to a mass spectrometer 132 (GC-MS, PekinElmer Clarus 600 C). Gas samples were collected from the chamber at 133 low temperature $\left(-30^{\circ} \mathrm{C}\right)$ onto Air Toxics tubes and analyzed through a thermal desorber 134 (TurboMatrix ${ }^{\mathrm{TM}} 150$ ATD), with split mode, followed by a thermal desorption at $300{ }^{\circ} \mathrm{C}$ 135 (5 min) delivering the sample to a $60-\mathrm{m}$ column (GasPro diameter $0.320 \mathrm{~mm}$ ). The $\mathrm{O}_{3}$ 136 and NO-NO ${ }_{x}$ concentrations were continuously monitored by UV absorption (HORIBA, 137 APOA 370) and chemiluminescence analyzer (HORIBA, APNA 360), respectively. 138 PF-3M2B was also monitored by PTR-TOF-MS (Proton Transfer Reaction - Time of 139 Flight-Mass Spectrometer, IONICON 8000). The fragment $\mathrm{CF}_{3}{ }^{+}(\mathrm{m} / z$ 68.986) and $140\left(\mathrm{CF}_{3}\right)_{2} \mathrm{CF}_{3}{ }^{+}(\mathrm{m} / \mathrm{z}$ 168.970) were used to monitor the temporal behavior of PF-3M2B 141 during the photolysis.

142 PF-2M3P and 2M3P were introduced into the chamber by placing known volumes 143 of liquid in a bubbler and then, flushed by purified air. Their concentrations were 144 derived based on the volume of the liquid introduced, the pressure and the temperature 
145 in the chamber using the ideal gas law. $\mathrm{PF}-3 \mathrm{M} 2 \mathrm{~B}$ and $\mathrm{SF}_{6}$ were introduced into the

146 chamber by streaming purified air through a calibrated stainless steel cylinder (4.87 L)

147 equipped with capacitance manometers. To compensate sampling flows from analytical

148 instruments and chamber leaks, a flow of purified air (15-25 L/min) was added

149 continuously during all experiments enabling a slight overpressure to be maintained,

150 thus avoiding any contamination from outside air. Dilution of the gas volume in the

151 chamber was determined by monitoring the decay of introduced amount of $\mathrm{SF}_{6}$

152 (monitored by FT-IR). This decay under dark conditions was found to be in the range

153 of $(5-20) \times 10^{-6} \mathrm{~s}^{-1}$.

154 Background concentrations in the chamber were systematically found to be below

155 the detection limits of analytical instruments (e.g., $\left[\mathrm{NO}_{\mathrm{x}}\right]<2.5 \times 10^{10},\left[\mathrm{O}_{3}\right]<2.5 \times 10^{10}$,

$156[$ VOC $]<1.3 \times 10^{8}$ molecule $\mathrm{cm}^{-3}$ ).

157

$158 \quad$ 2.2.2. $3.4 \mathrm{~m}^{3}$ outdoor chamber

159 Photolysis studies of PF-2M3P were also performed in the $3.4 \mathrm{~m}^{3}$ ICARE outdoor

160 atmospheric simulation chamber made of ethylene tetrafluoroethylene (ETFE) foil. The

161 light intensity was continuously monitored using a filter radiometer measuring the

162 photolysis frequency of $\mathrm{NO}_{2}, J_{\mathrm{NO} 2}$ (Meteorologie consult Gmbh, Germany). The

163 temperature and the relative humidity were also continuously measured using a

164 combined probe (Vaisala HMT330 series transmitters). Chemical analysis of the gas

165 mixture was characterized by an infrared spectrometer (Nicolet 550 Magna FT-IR 
167 meters). Infrared spectra were recorded every 5 minutes by co-adding 130

168 interferograms at a resolution of $1 \mathrm{~cm}^{-1}$. Rapid mixing of reactant was insured using a

169 fan made of Teflon mounted into the chamber. The dilution rate was estimated by

170 monitoring the loss of SF6. IR reference spectrum of PF-2M3P was obtained by

171 introducing a known volume of liquid in the chamber. During dark experiments, the

172 chamber was covered by a black and opaque curtain to protect it from sunlight radiation.

173 The curtain could be removed very quickly for exposure to solar radiation, thus

174 initiating the photolysis process. Experiments were performed at 1013 mbar of purified

175 air and in the temperature range of 306 to $319 \mathrm{~K}$. Initial concentrations of PF-2M3P

176 were in the range of $(0.89-2.7) \times 10^{14}$ molecule $\mathrm{cm}^{-3}$. The gas mixture was exposed to

177 solar irradiation for up to 4 hours.

178

179 2.3. Photolysis experiments

180 Under sunlight conditions, the investigated ketones, PF-2M3P, PF-3M2B and

181 2M3P may be removed by photolysis, dilution and wall loss processes following the 182 reactions:
183 ketones $+h v \rightarrow$ products
$J$
184 ketones $\rightarrow$ dilution and wall loss $\quad k \mathrm{~L}$
$185 \quad \mathrm{SF}_{6}$
$\rightarrow$ dilution
$k_{\mathrm{d}}$ 
187

188

190

191

192

193

194

195

196

197

198

where $J\left(\right.$ in s $\left.^{-1}\right)$ is their photolysis rate while $k_{\mathrm{L}}\left(\right.$ in s $^{-1}$ ) is their decay rates under the dark including dilution and wall loss. Under irradiation, the total decays of the investigated ketones are expressed as follows:

$\ln \left([\text { ketone }]_{\mathrm{o}} /[\text { ketone }]_{\mathrm{t}}\right)=k_{\text {tot }} \times t$

Eq. 2

with [ketone $]_{0}$ and $[\text { ketone }]_{\mathrm{t}}$ are the concentrations of PF-2M3P or PF-3M2B or 2M3P at times to and $\mathrm{t}$, respectively. $k_{\text {tot }}\left(\right.$ in $\left.^{-1}\right)$, the total decay rate of the studied compound under irradiation, is formulated as:

$k_{\mathrm{tot}}=J_{\text {meas }}+k_{\mathrm{d}, \mathrm{light}}+\left(k_{\mathrm{L}}-k_{\mathrm{d}, \mathrm{dark}}\right)$

Eq. 3

$J_{\text {meas }}$ is the photolysis rate obtained from the experiment measurement. $k_{\mathrm{d} \text {,dark }}$ and $k_{\mathrm{d}, \text { light }}\left(\right.$ in $^{-1}$ ) are, respectively, the dilution decay rates obtained from $\mathrm{SF}_{6}$ decay in the dark and during irradiation.

The atmospheric photolysis rate coefficient was calculated, $J_{\text {calc }}$, as follows:

$$
J_{\text {calc }}=\int \sigma(\lambda) \Phi(\lambda) \mathrm{F}(\lambda) \mathrm{d} \lambda(\lambda=290-400 \mathrm{~nm}) \quad \text { Eq. } 4
$$

where $\sigma(\lambda), \Phi(\lambda)$ and $F(\lambda)$ are the absorption cross-section, the quantum yield of dissociation and the actinic flux over the absorption 290 to $400 \mathrm{~nm}$, respectively. The actinic flux was directly measured by the spectroradiometer placed inside the chamber. Assuming a quantum yield of unity for the photodissociation process along the absorption region of $\mathrm{PF}-2 \mathrm{M} 3 \mathrm{P}$ or $\mathrm{PF}-3 \mathrm{M} 2 \mathrm{~B}$ or $2 \mathrm{M} 3 \mathrm{P}$, the maximum photolytic rate coefficient can be calculated, $J_{\max }=J_{\text {cal }}$ using Eq. 4. As a result, an effective photodissociation quantum yield can derived: 


\subsection{Chamber loss correction}

The concentrations of the products formed from the photolysis of PF-2M3P, PF-

$2113 \mathrm{M} 2 \mathrm{~B}$ and $2 \mathrm{M} 3 \mathrm{P}$ were corrected to account for dilution and possible photolysis/OH

212 reactions under irradiation using the following equation: ${ }^{10}$

$$
[\text { Product }]_{\text {corrected }}=[\text { Product }]_{\text {measured }} \times \mathrm{F}
$$

Eq. 6

214 with $\mathrm{F}$ being the correction factor: $\mathrm{F}=1+\Delta[$ Product $] /[\text { Product }]_{\text {measured }}$

215 The amount of product lost, $\Delta$ [Product] due to secondary reactions, i.e., dilution,

216 reaction with $\mathrm{OH}$ radical and photolysis processes is calculated from:

$$
\Delta[\text { Product }]=\int\left(k_{\mathrm{d}, \text { light }}+J_{\text {product }}+[\mathrm{OH}]^{*} \mathrm{k}\right) \times[\text { Product }]_{\text {measured }} \times \mathrm{dt} \quad \text { Eq. } 7
$$

219 using $F<1$ 1.2. For $\mathrm{HCHO}, \mathrm{CH}_{3} \mathrm{CHO}$ and $\mathrm{CH}_{3} \mathrm{COCH}_{3}$, photolysis, reaction with $\mathrm{OH}$

220 radical and dilution were considered and $F_{\mathrm{HCHO}}<1.52, F_{\mathrm{CH} 3 \mathrm{CHO}}<1.35$ and $F_{\mathrm{CH} 3 \mathrm{COCH} 3}$

$221<1.30$ were used for the corresponding corrections. $J_{\mathrm{HCHO}}$ measured by the 222 spectoradiometer and $J_{\mathrm{CH} 3 \mathrm{CHO}}$ and $J_{\mathrm{CH} 3 \mathrm{COCH} 3}$ were calculated using Eq. 4; 223 corresponding $\sigma(\lambda)$ and $\Phi(\lambda)$ values for $\mathrm{CH}_{3} \mathrm{CHO}$ and $\mathrm{CH}_{3} \mathrm{COCH}_{3}$ were taken from 224 IUPAC database ${ }^{11}$. The $\mathrm{OH}$ rate coefficients of $\mathrm{CO}, \mathrm{HCHO}, \mathrm{CH}_{3} \mathrm{CHO}$ and $\mathrm{CH}_{3} \mathrm{COCH}_{3}$ 225 were extracted from IUPAC kinetic database ${ }^{11}$ as $1.65 \times 10^{-13}, 8.5 \times 10^{-12}, 1.5 \times 10^{-11}$ and $2261.8 \times 10^{-13} \mathrm{~cm}^{3}$ molecule $\mathrm{e}^{-1} \mathrm{~s}^{-1}$ at $\mathrm{T}=298 \mathrm{~K}$. 


\subsection{Infrared absorption spectra}

230 Fourier transform infrared (FTIR) spectroscopy. Absorption spectra were recorded in

231250 co-adds between 700 and $4000 \mathrm{~cm}^{-1}$ at $1 \mathrm{~cm}^{-1}$ resolution (Happ-Genzel apodization).

232 A Whyte-type multi-pass absorption cell with 10 meters optical path length $(\mathrm{KBr}$

233 windows) was used in the course of these measurements. Absorption spectra, $A(v)$

234 (base e), (or integrated band strengths) were determined using Beer's law:

235

$$
\mathrm{A}(v)=\sigma(v) \times \mathrm{L} \times[\text { Ketones }] \quad \text { Eq. } 8
$$

236 where $\sigma(v)$ is the infrared absorption cross section of the ketones at wavenumber $v, L$

237 is the absorption path length, and [ketones] is the PF-2M3P, PF-3M2B, and 2M3P

238 concentration. Measurements were performed using the following concentration ranges

239 (in units of molecule $\left.\mathrm{cm}^{-3}\right):(1.2-10.8) \times 10^{14}$ for PF-2M3P, $(1.6-9.9) \times 10^{14}$ for PF-3M2B

240 and $(0.6-4.8) \times 10^{14}$ for $2 \mathrm{M} 3 \mathrm{P}$. Over the course of the study, replicate measurements

241 were performed using independently prepared gas mixtures with helium as bath gas.

242 The absorption spectra (band strengths) were obtained from a linear least-squares fit of

243 A versus [Ketones] that included at least 6 individual spectrum measurements.

\subsection{Chemicals}

246 The chemicals used in this work and their stated purities were as follows:

247 perfluoro-2-methyl-3-pentanone (99\%, 3M Belgium N.V, Chemical Group-EBC), 2- 
methyl-3-pentanone (97\%, Sigma-Aldrich), perfluoro-3-methyl-2-buytanone (98\%, Ugarit Chimie), $\mathrm{SF}_{6}$ (99.9995\%, Air Liquide) and $\mathrm{O}_{2}$ (99.9995\%, Air Liquide), Helium (99.9995\%, Air Liquide). PF-2M3P, PF-3M2B and 2M3P samples were further purified by using several freeze-pump-thaw cycles. GC-MS analysis of the samples did not show any observable impurities.

\section{Results and Discussion}

\subsection{UV absorption cross section}

To test the accuracy of the measurement methodology used in this work, the UV absorption spectrum of acetone has been measured and compared to the recommended UV spectrum from NASA/JPL evaluation. ${ }^{12}$ As shown in SI (Figure S1), the level of agreement between both measured and recommended spectra is high, within the measurement accuracy of the recommended UV-Vis absorption spectra $(\approx 8 \%)$. This excellent agreement provides confidence in the reliability of the absorption cross section measurement conducted in this work.

The measured UV-Visible absorption spectra of PF-2M3P, PF-3M2B and 2M3P between 220 and $400 \mathrm{~nm}$ at $(300 \pm 2) \mathrm{K}$ are depicted in Figure 1 and absorption cross sections are provided in Table S1. The quoted uncertainties originated from 2 standard deviation $(2 \sigma)$ of the average of individual measurements. The measurements satisfied Beer's law over a wide concentration range (an order of magnitude). The measured absorbance, A (base e) ranged from 0.2 to 1.7 for PF-2M3P, 0.1 to 1.0 for PF-3M2B, 
270 given in Figure S2.

$272 \mathrm{~cm}^{2}$ molecule $\left.{ }^{-1}\right)$ while PF-2M3P shows a maximum around $305 \mathrm{~nm}\left(\sigma_{(305 \mathrm{~nm})}=(6.50 \pm\right.$

$2730.28) \times 10^{-20} \mathrm{~cm}^{2}$ molecule ${ }^{-1}$ ) and PF-3M2B exhibits a maximum absorption at $300 \mathrm{~nm}$

$274\left(\sigma_{(300 \mathrm{~nm})}=(3.46 \pm 0.15) \times 10^{-20} \mathrm{~cm}^{2}\right.$ molecule $\left.{ }^{-1}\right)$. The UV absorption spectra obtained

275 in this work are compared with those reported in literature when possible and are

276 presented in Figure 1. The absorption spectrum of PF-2M3P is in agreement with the

277 reported one by Taniguchi et al., ${ }^{5}$ within $5 \%$. The absorption cross sections of $2 \mathrm{M} 3 \mathrm{P}$

278 obtained in the present work is higher than that reported by Díaz-de-Mera, et al. ${ }^{13}$ by

$27918 \%\left(\sigma_{\max }\right)$. To the best of our knowledge, the experimental UV spectrum of PF-3M2B

280 is reported for the first time here. Prior to this study, the UV spectrum of PF-3M2B was

281 also determined using a theoretical approach and found to be higher compared to this

282 work, within $27 \%$ at the maximum cross section. ${ }^{14}$

283 The absorption band of ketones is caused by the dipole forbidden $n-\pi^{*}$ transition

284 of the $\mathrm{C}=\mathrm{O}$ group. The maximum absorption of $\mathrm{PF}-2 \mathrm{M} 3 \mathrm{P}$ is red-shifted, i.e. around 20

$285 \mathrm{~nm}$, compared to $2 \mathrm{M} 3 \mathrm{P}$ caused by the electronegative substituents in $\alpha$ - $\alpha$ '-positions. ${ }^{15-}$

$286{ }^{17}$ In addition, the maximum absorption of PF-2M3P is about $\sim 2$ times higher than that 287 of PF-3M2B, which is consistent with the results of Mu and Mellouki ${ }^{8}$ who observed 288 that the peak UV cross section increased for larger aliphatic ketones.

289 The actinic flux in HELIOS at 13:00 ( $\pm 5 \mathrm{~min}$, local time) on $7^{\text {th }}$ of September 
2013 is also displayed on Figure 1. The integrated absorption cross sections over the

291 actinic flux region for PF-2M3P, 2M3P and PF-3M2B were determined to be $2.61 \times 10^{-}$

$292{ }^{18}, 1.22 \times 10^{-18}$ and $1.25 \times 10^{-18} \mathrm{~cm}^{2}$ molecule ${ }^{-1}$, respectively, indicating that one could

293 expect $J_{\mathrm{PF}-2 \mathrm{M} 3 \mathrm{P}}>J_{2 \mathrm{M} 3 \mathrm{P}} \approx J_{\mathrm{PF}-3 \mathrm{M} 2 \mathrm{~B}}$.

\subsection{Photolysis of perfluoro-2-methyl-3-pentanone}

Photolysis rate measurements. Experiments in the $3.4 \mathrm{~m}^{3}$ outdoor chamber were conducted in June-July 2010 at (306-319) K and RH<1\%. Temporal profiles of PF2M3P and $\mathrm{SF}_{6}$ concentrations were monitored under the dark for about 4 hours. No discernible loss other than dilution has been observed; the first order decay rates of PF$2 \mathrm{M} 3 \mathrm{P}$ and $\mathrm{SF}_{6}$ were in the order of $(6.6-8.1) \times 10^{-6} \mathrm{~s}^{-1}$. The chamber was then exposed to solar radiation, thus starting the photolysis. The photolysis rate of PF-2M3P, $J_{\mathrm{PF}-2 \mathrm{M} 3 \mathrm{P} \text {, }}$ was obtained by considering the total loss of PF-2M3P ( $\left.k_{\text {tot }}\right)$ and that from dilution which was obtained from the loss rate of $\mathrm{SF}_{6}\left(k_{\mathrm{d}}\right)$ under irradiation. Experimental details

304 and results derived from the four runs conducted are displayed in Table 1. For all 305 experiments, the photolysis rates of $\mathrm{NO}_{2}$ were in the range of $(4.4-5.5) \times 10^{-3} \mathrm{~s}^{-1}$. The 306 consumed fractions of PF-2M3P from photodissociation were between 2.1 and $3.7 \%$ 307 and the derived photolysis rates were $(1.7-2.8) \times 10^{-6} \mathrm{~s}^{-1}$ under our experimental 308 conditions $\left(J_{\mathrm{NO} 2}=(4.4-5.5) \times 10^{-3} \mathrm{~s}^{-1}\right)$. The quoted error corresponds to $2 \sigma$ obtained from 309 the least square analysis applied on the experimental data. The estimated error on $J_{\mathrm{PF}-}$ 
313 GC-MS for typically 2 hours in the dark and under natural irradiation for typically 4 to

3147 hours. The loss rates of $\mathrm{SF}_{6}$ and PF-2M3P were found to be similar in the dark,

315 equivalent to $(4.8-6.0) \times 10^{-6} \mathrm{~s}^{-1}$, indicating a minor loss on the chamber wall of PF-

316 2M3P. During irradiation, both FT-IR and ATD-GC-MS instruments showed a slightly

317 higher disappearance rate of $\mathrm{PF}-2 \mathrm{M} 3 \mathrm{P}$ than $\mathrm{SF}_{6}$ which indicated a possible photolysis

318 loss of PF-2M3P (ranging from 1.7 to $7.7 \%$ ) under our experimental conditions. The

319 photolysis rate of PF-2M3P, $J_{\mathrm{PF}-2 \mathrm{M} 3 \mathrm{P}}$ was determined to be $(1.1-3.8) \times 10^{-6}$ and $(1.1-$

$3203.6) \times 10^{-6} \mathrm{~s}^{-1}$ using Eq. 3, from FTIR and GC-MS measurements, respectively, with a

321 recommended range of $(1.1-3.8) \times 10^{-6} \mathrm{~s}^{-1}\left(\right.$ with $\left.J_{\mathrm{NO} 2}=(3.0-5.6) \times 10^{-3} \mathrm{~s}^{-1}\right)$.

322 Table 2 summarizes the photolysis rates of PF-2M3P obtained in this work and

323 those reported in the literature. The values from this work were lower than those

324 reported by D'Anna, et al. ${ }^{18}$ Díaz-de-Mera, et al. ${ }^{13}$ who also conducted experiments

325 under natural irradiation in Spain. In contrast, the experiments conducted under

326 artificial irradiation using black lamps or sunlamps led to lower photolysis rate values

327 . It should be noted that the measured photolysis rate from this work agreed with the 328 result from the TUV model ${ }^{19}$ run at different seasons of the year (Table S2).

329 The maximum photolysis rate of PF-2M3P, $J_{\text {max-PF-2M3P, was estimated using }}$ 330 absorption cross sections and the actinic flux measured in this work (Eq. 4) and found 331 to be in the range of $(0.7-1.2) \times 10^{-4} \mathrm{~s}^{-1}$. Therefore, the observed photolysis rate 
corresponds to an effective quantum yield of $\emptyset_{\mathrm{eff}}=0.015-0.035$, which is in agreement

333 with the values reported by D'Anna, et al. ${ }^{18}$ and Díaz-de-Mera, et al. ${ }^{13}, 0.043 \pm 0.011$

334 and $0.044 \pm 0.006$, respectively.

344 linear least-square fit applied to the experimental data as shown in Figure S5 (HELIOS)

345 and Figure S6 (3.4 $\mathrm{m}^{3}$ chamber) and summarized in Table S3. The recommended

346 formation yields of products $( \pm 2 \sigma)$ from the photolysis of PF-2M3P are: $(74 \pm 18) \%$,

$347(193 \pm 84) \%$, and $(204 \pm 68) \%$ for $\mathrm{CF}_{3} \mathrm{C}(\mathrm{O}) \mathrm{F}, \mathrm{COF}_{2}$, and $\mathrm{CO}$, respectively. The carbon

348 and fluorine budgets were estimated to $(90 \pm 28) \%$ and $(57 \pm 18) \%$, respectively. This

349 suggests a large fraction of unidentified fluorine-containing products. Indeed,

350 Taniguchi, et al. ${ }^{5}$ identified $\mathrm{CF}_{3} \mathrm{O}_{3} \mathrm{CF}_{3}$ and $\mathrm{CF}_{3} \mathrm{OH}$ as photolysis products that were not 351 identified in the present work. 
353 photolysis of PF-2M3P is shown in Figure S7. The photodissociation of PF-2M3P may

354 occur through a $\mathrm{C}-\mathrm{C}$ bond cleavage in the $\alpha$-position of the carbonyl group to produce 355 perfluoroalkyl and perfluoroacetyl radicals:

$\mathrm{CF}_{3} \mathrm{CF}_{2} \mathrm{C}(\mathrm{O}) \mathrm{CF}\left(\mathrm{CF}_{3}\right)_{2}+h v \rightarrow \mathrm{CF}_{3} \mathrm{CF}_{2}+\mathrm{C}(\mathrm{O}) \mathrm{CF}\left(\mathrm{CF}_{3}\right)_{2}$

$$
\rightarrow \mathrm{CF}_{3} \mathrm{CF}_{2} \mathrm{C}(\mathrm{O})+\mathrm{CF}\left(\mathrm{CF}_{3}\right)_{2}
$$

358 Perfluoroacetyl radicals are expected to either decompose to give $\mathrm{CO}$ and 359 perfluoroalkyl radical:

360

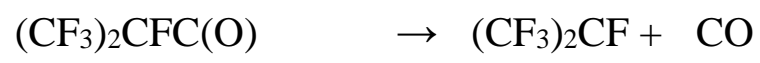

362 or react with $\mathrm{O}_{2}$ leading to the corresponding peroxy radicals:

$363\left(\mathrm{CF}_{3}\right)_{2} \mathrm{CFC}(\mathrm{O})+\mathrm{O}_{2}+\mathrm{M} \rightarrow\left(\mathrm{CF}_{3}\right)_{2} \mathrm{CFC}(\mathrm{O}) \mathrm{O}_{2}$

$364 \mathrm{CF}_{3} \mathrm{CF}_{2} \mathrm{C}(\mathrm{O})+\mathrm{O}_{2}+\mathrm{M} \rightarrow \mathrm{CF}_{3} \mathrm{CF}_{2} \mathrm{C}(\mathrm{O}) \mathrm{O}_{2}+\mathrm{M}$

The high formation yield of CO $(204 \pm 68) \%$ indicates that the thermal

366 decomposition is an important pathway in the fate of perfluoroacetyl radical over the 367 reaction with $\mathrm{O}_{2}$.

$368 \mathrm{CF}_{3} \mathrm{COF}$ and $\mathrm{COF}_{2}$, identified among the photolysis products $(74 \pm 18) \%$ and $369(193 \pm 84) \%$, respectively, might originate from the reactions of $\mathrm{CF}_{3} \mathrm{CF}_{2} \mathrm{O}_{2}$ and $370\left(\mathrm{CF}_{3}\right)_{2} \mathrm{CFCO}_{2}$ radicals with $\mathrm{RO}_{2}$ radicals present in the system leading to the 371 corresponding $\mathrm{RO}$ radicals as $\left(\mathrm{CF}_{3}\right)_{2} \mathrm{CFCO}$ and $\mathrm{CF}_{3} \mathrm{CF}_{2} \mathrm{O}$ radicals, which would 
372 thermally decompose to form $\mathrm{CF}_{3}$ radicals and the corresponding fluorinated carbonyls

$373 \mathrm{CF}_{3} \mathrm{C}(\mathrm{O}) \mathrm{F}$ and $\mathrm{COF}_{2} .{ }^{20}$ In addition, $\mathrm{CF}_{3} \mathrm{CF}_{2} \mathrm{OH}$ and $\mathrm{CF}_{3} \mathrm{OH}$, formed from $\mathrm{CF}_{3} \mathrm{CF}_{2} \mathrm{O}$

374 and $\mathrm{CF}_{3} \mathrm{O}$ radicals reaction with hydrogen-containing compounds present in the

375 chamber (e.g., HCHO desorbing from the chamber walls, impurities in the air diluent,

376 or water), were also reported to transform rapidly into $\mathrm{COF}_{2} .^{21-22}$

\subsection{Photolysis of 2-methyl-3-pentanone}

Photolysis rate measurements. Mixtures of $2 \mathrm{M} 3 \mathrm{P} / \mathrm{SF}_{6} /$ air were added into

HELIOS and left in the dark typically for 2 hours before irradiation by solar light. The

loss rates of $\mathrm{SF}_{6}$ and $2 \mathrm{M} 3 \mathrm{P}$ in the dark were determined to be $(4.8-6.2) \times 10^{-6}$ and $(5.2-$

6.8) $\times 10^{-6} \mathrm{~s}^{-1}$, respectively. The chemical mixture $2 \mathrm{M} 3 \mathrm{P} / \mathrm{SF}_{6} /$ air was then exposed to

383 solar irradiation for typically 5-6 hours. Under these experimental conditions, the

384 measured loss of 2M3P ranged from 3.9 to $6.3 \%$. The determination of $J_{2 \mathrm{M} 3 \mathrm{P}}$ from FTIR

385 and GC-MS measurements were in good agreement, within (3-7) \%. The experimental

386 conditions and the obtained values of $J_{2 \mathrm{M} 3 \mathrm{P}}$ are summarized in Table 1.

All the experiments were performed in the absence of $\mathrm{OH}$ radical scavenger to

388 avoid spectral interferences in the mid-infrared region with the studied compounds.

389 Therefore, the gas phase removal of $2 \mathrm{M} 3 \mathrm{P}$ during solar exposure might also due to the

390 reaction of $\mathrm{OH}$ radicals with $2 \mathrm{M} 3 \mathrm{P}$ in addition to its photolysis. Indeed, when the

391 chamber was only filled with purified air and exposed to solar irradiation, separate

392 measurements using a chemical ionization mass spectrometer (CIMS) have shown the 
393 presence of $\mathrm{OH}$ radicals at concentration ranging from $(2.1 \pm 0.9) \times 10^{5}$ occasionally up

394 to $2 \times 10^{6}$ molecule $\mathrm{cm}^{-3}$ could be observed. This implied that under these conditions,

395 the $\mathrm{OH}$ reaction contribution to the total loss of $2 \mathrm{M} 3 \mathrm{P}$ would have contributed from $30 \%$

396 to $100 \%$. However, it has been also observed that the disappearance rate of $2 \mathrm{M} 3 \mathrm{P}$

397 during solar exposure during this study was very comparable to those of PF-2M3P and

398 PF-3M2B (Table 1), suggesting that the $\mathrm{OH}$ concentration level during these

399 experiments was very low. Therefore, in the absence of $\mathrm{OH}$ radical direct measurement

400 during this study, we preferred to be conservative and thus, recommend an upper limit

401 for the photolysis rate of $2 \mathrm{M} 3 \mathrm{P}$, equivalent to $(2.6 \pm 1.4) \times 10^{-6} \mathrm{~s}^{-1}$ (with $J_{\mathrm{NO} 2}=5.6 \times 10^{-3}$

$\left.402 \mathrm{~s}^{-1}\right)$.

403 Based on the integrated UV absorption spectrum over the actinic flux region, the

404 derived maximum photolysis rate constant of $2 \mathrm{M} 3 \mathrm{P}, J_{\max -2 \mathrm{M} 3 \mathrm{P}}$, was found to be (6.5-

$4059.6) \times 10^{-6} \mathrm{~s}^{-1}$. Therefore, the effective photolysis quantum yield is estimated to be $\emptyset_{\text {eff }}$

$406=\leq 0.28$ under tropospheric sunlight conditions.

407

408 Products and mechanism. Products were identified and quantified using FT-IR

409 spectroscopy. The Figure S8 displays the typical spectra acquired before and after the

410 photolysis of 2M3P. Comparison of measured calibrated IR spectra shows the presence

411 of $\mathrm{CH}_{3} \mathrm{CHO}, \mathrm{CO}, \mathrm{CH}_{3} \mathrm{COCH}_{3}$ and $\mathrm{HCHO}$ among the oxidation products where an

412 example of time-concentration profiles of 2M3P and its products is shown in Figure S9.

413 These products have been observed to be of primary origin when $2 \mathrm{M} 3 \mathrm{P}$ was exposed 
414 to natural irradiation (Figure S10). As explained previously, derived formation yields

415 of products, possibly accounted for both contributions of photolysis and $\mathrm{OH}$ reactions, 416 were estimated to $(81 \pm 18) \%,(25 \pm 6) \%,(90 \pm 16) \%$ and $(98 \pm 10) \%$ for $\mathrm{CH}_{3} \mathrm{CHO}, \mathrm{HCHO}$, $417 \mathrm{CH}_{3} \mathrm{COCH}_{3}$ and $\mathrm{CO}$, respectively.-Therefore, due to unquantified contribution of $\mathrm{OH}$ 418 reaction to the formation yields of products during this photolysis study, we prefer to 419 conclude qualitatively on the formation of $\mathrm{CH}_{3} \mathrm{CHO}, \mathrm{HCHO}, \mathrm{CH}_{3} \mathrm{COCH}_{3}$ and $\mathrm{CO}$ 420 among the photolysis products from the irradiation of $2 \mathrm{M} 3 \mathrm{P}$.

421 Figure S11 shows the proposed mechanistic pathways leading to the formation of 422 the observed products. The photolysis of 2M3P may occur via $\mathrm{C}-\mathrm{C}$ bond cleavage 423 associated with $\mathrm{C}=\mathrm{O}$ group to form an alkyl and the corresponding acetyl radical:

$\mathrm{CH}_{3} \mathrm{CH}_{2} \mathrm{C}(\mathrm{O}) \mathrm{CH}\left(\mathrm{CH}_{3}\right)_{2}+h v \rightarrow \mathrm{CH}_{3} \mathrm{CH}_{2}+\mathrm{C}(\mathrm{O}) \mathrm{CH}\left(\mathrm{CH}_{3}\right)_{2}$

$\mathrm{CH}_{3} \mathrm{CH}_{2} \mathrm{C}(\mathrm{O}) \mathrm{CH}\left(\mathrm{CH}_{3}\right)_{2}+h v \rightarrow \mathrm{CH}_{3} \mathrm{CH}_{2} \mathrm{C}(\mathrm{O})+\mathrm{CH}\left(\mathrm{CH}_{3}\right)_{2}$

$\mathrm{CH}_{3} \mathrm{CH}_{2} \mathrm{C}(\mathrm{O})$ and $\mathrm{C}(\mathrm{O}) \mathrm{CH}\left(\mathrm{CH}_{3}\right)_{2}$ radicals, are expected to either decompose to alkyl radicals $\left(\mathrm{CH}_{3} \mathrm{CH}_{2}\right.$ and $\left.\left(\mathrm{CH}_{3}\right)_{2} \mathrm{CH}\right)$ leading to $\mathrm{CO}$ elimination or react with $\mathrm{O}_{2}$ to 428 form the corresponding acetyl peroxy radicals $\left(\left(\mathrm{CH}_{3}\right)_{2} \mathrm{CHC}(\mathrm{O}) \mathrm{O}_{2}\right.$ and $\left.\mathrm{CH}_{3} \mathrm{CH}_{2} \mathrm{C}(\mathrm{O}) \mathrm{O}_{2}\right)$.

$429 \mathrm{CO}$ formation indicating the occurrence of at least one of the decomposition channels 43012 and 13: 
acid and $\mathrm{O}_{3}$ among the photolysis products indicates that the reaction of acetyl peroxy radicals with $\mathrm{HO}_{2}$ was insignificant under our experimental conditions. $\mathrm{CH}_{3} \mathrm{CH}_{2} \mathrm{C}(\mathrm{O}) \mathrm{O}$ and $\left(\mathrm{CH}_{3}\right)_{2} \mathrm{CHC}(\mathrm{O}) \mathrm{O}$ radicals are expected to decompose to form the corresponding alkyl radicals, $\mathrm{CH}_{3} \mathrm{CH}_{2}$ and $\left(\mathrm{CH}_{3}\right)_{2} \mathrm{CH}$, respectively. ${ }^{23-24}$

As shown in Figure $\mathrm{S} 11$, the subsequent reaction of $\mathrm{CH}_{3} \mathrm{CH}_{2}$ and $\left(\mathrm{CH}_{3}\right)_{2} \mathrm{CH}$ with $\mathrm{O}_{2}$ would form the corresponding peroxy radicals, $\mathrm{CH}_{3} \mathrm{CH}_{2} \mathrm{O}_{2}$ and $\left(\mathrm{CH}_{3}\right)_{2} \mathrm{CHO}_{2}$. The self-reaction of $\mathrm{CH}_{3} \mathrm{CH}_{2} \mathrm{O}_{2}$ radical would lead to the formation of $\mathrm{CH}_{3} \mathrm{CH}_{2} \mathrm{O}$ radical $(60 \%)$ and $\mathrm{CH}_{3} \mathrm{CHO}+\mathrm{CH}_{3} \mathrm{CH}_{2} \mathrm{OH}(40 \%) .{ }^{12}$ In addition, the $\left(\mathrm{CH}_{3}\right)_{2} \mathrm{CHO}_{2}$ radical selfreaction would lead to the formation of $\left(\mathrm{CH}_{3}\right)_{2} \mathrm{CHO}$ radical $(60 \%)$ and $\mathrm{CH}_{3} \mathrm{C}(\mathrm{O}) \mathrm{CH}_{3}+$ $\left(\mathrm{CH}_{3}\right)_{2} \mathrm{CHOH}(40 \%) . \mathrm{CH}_{3} \mathrm{CH}_{2} \mathrm{O}$ and $\left(\mathrm{CH}_{3}\right)_{2} \mathrm{CHO}$ alkoxy radicals are expected to react with $\mathrm{O}_{2}$ to form $\mathrm{HCHO}, \mathrm{CH}_{3} \mathrm{CHO}$ and $\mathrm{CH}_{3} \mathrm{C}(\mathrm{O}) \mathrm{CH}_{3}$.

\subsection{Photolysis of perfluoro-3-methyl-2-butanone}

PF-3M2B/SF6/air mixtures were monitored for 2 hours in the dark in HELIOS.

The dark loss rates of $\mathrm{SF}_{6}$ and $\mathrm{PF}-3 \mathrm{M} 2 \mathrm{~B}$ were similar and found to be $(1.1-1.3) \times 10^{-5}$ $\mathrm{s}^{-1}$. The gas mixture PF-3M2B /SF 6 /air was exposed to solar irradiation for typically 56 hours. PF-3M2B was monitored by FTIR and PTR-TOF-MS $\left(\mathrm{CF}_{3}{ }^{+}\right.$and $\left(\mathrm{CF}_{3}\right)_{2} \mathrm{CF}_{3}{ }^{+}$ ions at $\mathrm{m} / \mathrm{z} 68.986$ and $\mathrm{m} / \mathrm{z}, 168.970$, respectively). The observed loss of PF-3M2B ranged from 1.3 to $2.0 \%$ depending on the solar light intensity. The obtained photolysis rate was $J_{\mathrm{PF}-3 \mathrm{M} 2 \mathrm{~B}}=(9 \pm 5) \times 10^{-7} \mathrm{~s}^{-1}$ with $J_{\mathrm{NO} 2}=(4.2-7.7) \times 10^{-3} \mathrm{~s}^{-1}$. The experimental conditions and the corresponding results are summarized in Table 1. The TUV model 
was also used to calculate the PF-3M2B photolysis loss rates at the different period of year, ranging from $2 \times 10^{-7} \mathrm{~s}^{-1}$ to $1.2 \times 10^{-6} \mathrm{~s}^{-1}$. No detectable formation of products was observed from the photolysis of PF-3M2B due to its low photolysis rate and to the detection limits of the analytical techniques used.

461 using the integrated UV absorption spectrum over the actinic flux region and found to be $J_{\text {max-PF-3M2B }}=(2.9-5.6) \times 10^{-5} \mathrm{~s}^{-1}$. The measured photolysis rate led to an effective

463 photolysis quantum yield estimated to $\emptyset_{\text {eff }} \leq 0.037$ under tropospheric sunlight 464 conditions.

\subsection{Infrared absorption and global warming potential (GWP)}

The infrared absorption spectra of the PF-2M3P and PF-3M2B measured in this

468 work are characterized by broad diffuse vibrational bands as shown in Figure 3, 469 (digitized absorption spectra are provided in SI as .txt format). The spectra are 470 characterized by strong absorption features in the C-F stretch regions, $1200-1400 \mathrm{~cm}^{-1}$.

471 Overall, the larger perfluorinated ketones have greater peak cross sections in this region 472 due, in part, to the greater overlap of vibrational bands. The infrared spectrum of $2 \mathrm{M} 3 \mathrm{P}$ 473 is also characterized by broad vibrational band, due to absorption features of $\mathrm{C}-\mathrm{H}$ 474 stretch regions. The IR spectrum of $2 \mathrm{M} 3 \mathrm{P}$ is also characterized by a sharp absorption 475 at $1700 \mathrm{~cm}^{-1}$, corresponding to $\mathrm{C}=\mathrm{O}$ stretch vibration (Figure 3). Corresponding 476 graphical representations of Beer's law fits are given in Figures S12, S13 and S14. 

to be $3.68 \times 10^{-16}, 3.03 \times 10^{-16}$ and $1.0 \times 10^{-16} \mathrm{~cm}^{2}$ molecule ${ }^{-1} \mathrm{~cm}^{-1}$ (base $e$ ) for PF-2M3P, PF-3M2B and 2M3P, respectively. Integrated band strengths of PF-2M3P over the 700$4802000 \mathrm{~cm}^{-1}$ IR spectral region reported by Díaz-de-Mera, et al. ${ }^{13}\left(3.94 \times 10^{-16} \mathrm{~cm}^{2}\right.$ 481 molecule $\left.^{-1} \mathrm{~cm}^{-1}\right)$ and D'Anna, et al. ${ }^{18}\left(4.05 \times 10^{-16} \mathrm{~cm}^{2}\right.$ molecule $\left.\mathrm{cm}^{-1}\right)$ are in 482 agreement with the present results, within $7 \%$ and $9 \%$, respectively. To the best of our 483 knowledge, IR spectra of PF-3M2B and 2M3P are reported for the first time in this 484 work.

The radiative efficiencies (RE) for the investigated ketones were calculated using the experimentally measured spectra and the method given in Hodnebrog, et al.

488 for PF-2M3P, PF-3M2B and 2M3P, respectively for atmospherically well-mixed 489 conditions and $+10 \%$ stratospheric temperature correction.

491 due to their expected short atmospheric lifetimes, < 13 days, and low atmospheric 492 abundances. Therefore, lifetime-adjusted RE, accounting for non-uniform horizontal 493 and vertical mixing for very short-lived compounds, was preferred and calculated to be $4940.012-0.036, \sim 0.036$ and $\leq 4 \times 10^{-8} \mathrm{~W} \mathrm{~m}^{-2} \mathrm{ppbv}^{-1}$ for PF-2M3P, PF-3M2B and 2M3P, 495 respectively. Corresponding GWPs (for 100 years horizon) were found to be $<0.21$, $496 \sim 0.29$ and $\leqslant 1.3 \times 10^{-7}$ for PF-2M3P, PF-3M2B and 2M3P, respectively, showing a 497 minor contribution of the studied ketones to the global warming potential. As shown in 


\section{Atmospheric implications}

4-14 days. ${ }^{5-6,13,18}$ The hydrolysis as removal process was demonstrated to be too slow to be considered of atmospheric importance. ${ }^{5-6}$ Besides, due to a high air-water partition coefficient, ${ }^{26}$ very low quantities of PF-2M3P will be present in the cloud droplets.

510 Based on the upper limits for the reaction rate coefficients (in units of $\mathrm{cm}^{3}$ molecule ${ }^{-1}$

$\left.511 \mathrm{~s}^{-1}\right)$ with $\mathrm{OH}$ radical $\left(<5 \times 10^{-16}\right), \mathrm{O}_{3}\left(<4 \times 10^{-22}\right)$ and $\mathrm{Cl}$ atoms $\left(<1.7 \times 10^{-19}\right)$ taken from

512 Taniguchi, et al. ${ }^{5}$ and typical global average tropospheric concentrations (in molecule $513 \mathrm{~cm}^{-3}$ ) of $\mathrm{OH} \sim 2 \times 10^{6},{ }^{27} \mathrm{Cl} \sim 10^{4},{ }^{28}$ and $\mathrm{O}_{3} \sim 7 \times 10^{11},{ }^{29}$ the tropospheric lifetime towards

$514 \mathrm{OH}, \mathrm{Cl}$ and $\mathrm{O}_{3}$ reactions is equivalent to $>30$ years. Thus, it is concluded that the 515 photolysis will be the dominant atmospheric loss process for PF-2M3P. Based on the photolysis rate measurement of PF-3M2B under natural irradiation

$517\left(J_{\mathrm{PF}-3 \mathrm{M} 2 \mathrm{~B}}=(9 \pm 5) \times 10^{-7} \mathrm{~s}^{-1}\right)$, an atmospheric lifetime with respect to photolysis of $\sim 13$ 518 days was derived. To the best of our knowledge, this work provides the first photolysis 
519 study of PF-3M2B. By analogy with PF-2M3P, other processes such as reactions with

$520 \mathrm{OH}$ radical, $\mathrm{Cl}$ and $\mathrm{O}_{3}$ and hydrolysis would not contribute significantly to the

521 atmospheric removal of PF-3M2B.

522 Using the photolysis rates of $2 \mathrm{M} 3 \mathrm{P}$ measured under natural irradiation $\left(J_{2 \mathrm{M} 3 \mathrm{P}}=\right.$

$\left.523 \leq(2.6 \pm 1.4) \times 10^{-6} \mathrm{~s}^{-1}\right)$, an atmospheric lifetime with respect to photolysis of $\geq 4$ days was

524 derived. In addition to photolysis, gas phase reactions with $\mathrm{OH}$ radical and $\mathrm{Cl}$ atom

525 could also contribute significantly to the tropospheric loss of $2 \mathrm{M} 3 \mathrm{P}$. Indeed,

526 tropospheric lifetimes towards $\mathrm{OH}$ and $\mathrm{Cl}$ reactions were derived to be $\approx 4(\mathrm{OH}$ rate

527 coefficient estimated from SAR) ${ }^{30}$ and 11 days ${ }^{31}$, respectively. Thus, both photolysis

528 and gas phase loss processes will contribute to the loss of 2M3P in the troposphere.

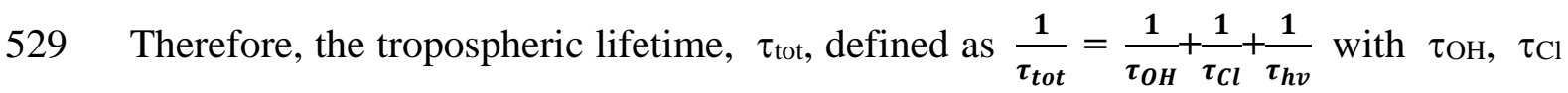

530 and $\tau \mathrm{OH}$, the corresponding lifetimes with respect to photolysis and $\mathrm{OH}$ radical and $\mathrm{Cl}$

531 reactions, respectively, was estimated to be 1-2 days.

532 Based on the present study, the photolysis of PF-2M3P has been found to produce

$533 \mathrm{CF}_{3} \mathrm{C}(\mathrm{O}) \mathrm{F}, \mathrm{COF}_{2}$, TFA, PFPrA, and $\mathrm{CO}$ under natural conditions. In the atmosphere,

$534 \mathrm{CF}_{3} \mathrm{C}(\mathrm{O}) \mathrm{F}$ will mainly hydrolyze to give trifluoroacetic acid (TFA, $\left.\mathrm{CF}_{3} \mathrm{C}(\mathrm{O}) \mathrm{OH}\right)$. In

535 the lower atmosphere, $\mathrm{COF}_{2}$ will be lost through hydrolysis, ${ }^{32-33}$ whereas in the

536 stratosphere, the photolysis is the dominant pathway producing $\mathrm{CO}_{2}$ and $\mathrm{HF}^{34}$ leading

537 to a local lifetime of 5-10 days. ${ }^{35}$

538 The photolysis of $2 \mathrm{M} 3 \mathrm{P}$ in the troposphere will lead to the formation of

$539 \mathrm{CH}_{3} \mathrm{C}(\mathrm{O}) \mathrm{CH}_{3}, \mathrm{CH}_{3} \mathrm{CHO}, \mathrm{HCHO}$ and $\mathrm{CO}$. The major atmospheric loss of $\mathrm{CH}_{3} \mathrm{C}(\mathrm{O}) \mathrm{CH}_{3}$, 
$\mathrm{CH}_{3} \mathrm{CHO}$ and $\mathrm{HCHO}$ is controlled by photolysis and reaction with $\mathrm{OH}$ radical. Their

541 photolysis are a source of $\mathrm{HO}_{\mathrm{x}}\left(\mathrm{OH}, \mathrm{HO}_{2}\right)$ in the upper troposphere. ${ }^{16,36}$

542 Finally, the low GWP values and the short atmospheric lifetimes for the studied

543 ketones may not lead to a large impact on the global warming of the Earth's atmosphere

544 but may have some impact regarding the formation of other fluorinated species.

\section{ASSOCIATED CONTENT}

\section{Supporting Information}

548 UV absorption cross section of PF-2M3P, PF-3M2B and 2M3P are provided in Table

549 S1 and Beer's law fits in Figure S2; UV absorption spectra of acetone is displayed in

550 Figure S1; Seasonal dependence of the photolysis rate of PF-2M3P, PF-3M2B and

551 2M3P simulated using TUV Model is tabulated in Table S2; Figures S3 and S4

552 represents the FTIR spectra and GC-MS spectrum, respectively and were used to obtain

553 the products yield as shown in Figures S5 and S6. Formation yields from the photolysis

554 of PF-2M3P are summarized in Table S3. Corresponding photolysis pathway is

555 proposed in Figure S7; Figure S8 presents the FTIR spectra from irradiation of 2M3P.

556 Figure S10 presents the data used to derive the formation yield of products from the

557 loss of 2M3P (Figure S9). Corresponding proposed photolysis pathway is given in

558 Figure S11. Infrared absorption cross sections of 2M3P, PF-2M3P and PF-3M2B (.txt

559 format) used to calculate radiative efficiencies (RE) and GWPs (100 years) (Table S4)

560 and the fitting according to Beer's law (Figure S12, Figure 13 and Figure S14).

562 AUTHOR INFORMATION

563 Corresponding Author

$564 *$ Tel: 33 (0)2 382576 12; e-mail: mellouki@ cnrs-orleans.fr.

565 ORCID

566 Yangang Ren: 0000-0001-5770-5050

567 François Bernard: 0000-0002-6116-3167

568 Véronique Daële: 0000-0003-2509-4077

569 Abdelwahid Mellouki: 0000-0002-6594-5262

573 Acknowledgments 
574 This work is supported by Labex Voltaire (ANR-10-LABX-100-01), ARD PIVOTS

575 program (supported by the Centre-Val de Loire regional council), and the European

576 Union's Horizon 2020 research and innovation programme through the

577 EUROCHAMP-2020 Infrastructure Activity under grant agreement No. 730997.

578 
580 (1) Forrest, E. C.; Hu, L.-W.; Buongiorno, J.; McKrell, T. J., Pool Boiling Heat 581 Transfer Performance of a Dielectric Fluid With Low Global Warming Potential. Heat 582 Transfer Eng. 2013, 34 (15), 1262-1277.

583 (2) Yao, B.; Vollmer, M. K.; Zhou, L. X.; Henne, S.; Reimann, S.; Li, P. C.; Wenger, 584 A.; Hill, M., In-situ measurements of atmospheric hydrofluorocarbons (HFCs) and 585 perfluorocarbons (PFCs) at the Shangdianzi regional background station, China. Atmos. 586 Chem. Phys. 2012, 12 (21), 10181-10193.

587 (3) Schaefer, D. O.; Godwin, D.; Harnisch, J., Estimating Future Emissions and 588 Potential Reductions of HFCs, PFCs, and $\mathrm{SF}_{6}$. Energy J. 2006, 27, 63-88.

589 (4) Hyrenbach, M. In Alternative gas insulation in medium-voltage switchger, 23rd 590 International Conference on Electricity Distribution, Lyon, 15-18 June; Lyon, 2015.

591 (5) Taniguchi, N.; Wallington, T. J.; Hurley, M. D.; Guschin, A. G.; Molina, L. T.; 592 Molina, M. J., Atmospheric Chemistry of $\mathrm{C}_{2} \mathrm{~F} 5 \mathrm{C}(\mathrm{O}) \mathrm{CF}\left(\mathrm{CF}_{3}\right)_{2}$ : Photolysis and Reaction 593 with Cl Atoms, OH Radicals, and Ozone. J. Phys. Chem. A 2003, 107 (15), 2674-2679.

594 (6) Jackson, D. A.; Young, C. J.; Hurley, M. D.; Wallington, T. J.; Mabury, S. A., 595 Atmospheric Degradation of Perfluoro-2-methyl-3-pentanone: Photolysis, Hydrolysis 596 and Hydration. Environ. Sci. Technol. 2011, 45 (19), 8030-8036.

(7) Hyrenbach, M.; Zache, S. In Alternative insulation gas for medium-voltage switchgear, 2016 Petroleum and Chemical Industry Conference Europe (PCIC Europe),

600 (8) Mu, Y. J.; Mellouki, A., The near-UV absorption cross sections for several ketones. 601 J. Photochem. Photobiol., A 2000, 134 (1-2), 31-36.

602 (9) Ren, Y.; Grosselin, B.; Daele, V.; Mellouki, A., Investigation of the reaction of 603 ozone with isoprene, methacrolein and methyl vinyl ketone using the HELIOS 604 Chamber. Faraday Discussions 2017, 200 (0), 289-311.

605 (10) Volkamer, R.; Platt, U.; Wirtz, K., Primary and Secondary Glyoxal Formation 606 from Aromatics: Experimental Evidence for the Bicycloalkyl-Radical Pathway from 607 Benzene, Toluene, and p-Xylene. J. Phys. Chem. A 2001, 105 (33), 7865-7874.

608 (11) Atkinson, R.; Baulch, D. L.; Cox, R. A.; Crowley, J. N.; Hampson, R. F.; Hynes, 609 R. G.; Jenkin, M. E.; Rossi, M. J.; Troe, J.; Subcommittee, I., Evaluated kinetic and 610 photochemical data for atmospheric chemistry: Volume II \&ndash; gas phase reactions 611 of organic species. Atmos. Chem. Phys. 2006, 6 (11), 3625-4055.

612 (12) J. B. Burkholder; S. P. Sander; J. Abbatt; J. R. Barker; R. E. Huie; C. E. Kolb; M. 613 J. Kurylo; V. L. Orkin; D. M. Wilmouth; Wine, P. H., Chemical Kinetics and 614 Photochemical Data for Use in Atmospheric Studies, Evaluation No. 18. JPL 615 Publication 15-10, J. P. L., Ed. Pasadena, 2015.

616 (13) Díaz-de-Mera, Y.; Aranda, A.; Notario, A.; Rodriguez, A.; Rodriguez, D.; Bravo, 617 I., Photolysis study of fluorinated ketones under natural sunlight conditions. Phys. 618 Chem. Chem. Phys. 2015, 17 (35), 22991-22998. 

butanone [CF3C $(\mathrm{O}) \mathrm{CF}(\mathrm{CF} 3) 2]$ : Photodissociation and Reaction with $\mathrm{OH}$ Radicals. $J$. Phys. Chem. A 2018, 122 (45), 8840-8848.

(15) Chiappero, M. S.; Malanca, F. E.; Argüello, G. A.; Wooldridge, S. T.; Hurley, M. D.; Ball, J. C.; Wallington, T. J.; Waterland, R. L.; Buck, R. C., Atmospheric Chemistry of Perfluoroaldehydes $\left(\mathrm{C}_{\mathrm{x}} \mathrm{F}_{2 \mathrm{x}+1} \mathrm{CHO}\right)$ and Fluorotelomer Aldehydes $\left(\mathrm{C}_{\mathrm{x}} \mathrm{F}_{2 \mathrm{x}+1} \mathrm{CH}_{2} \mathrm{CHO}\right)$ : Quantification of the Important Role of Photolysis. J. Phys. Chem. A 2006, 110 (43), 11944-11953.

(16) Simpson, W. R.; von Glasow, R.; Riedel, K.; Anderson, P.; Ariya, P.; Bottenheim, J.; Burrows, J.; Carpenter, L. J.; Frieß, U.; Goodsite, M. E.; Heard, D.; Hutterli, M.; Jacobi, H. W.; Kaleschke, L.; Neff, B.; Plane, J.; Platt, U.; Richter, A.; Roscoe, H.; Sander, R.; Shepson, P.; Sodeau, J.; Steffen, A.; Wagner, T.; Wolff, E., Halogens and their role in polar boundary-layer ozone depletion. Atmos. Chem. Phys. 2007, 7 (16), 4375-4418.

(17) Metcalfe, J.; Phillips, D., Photophysical processes in fluorinated acetones. $J$. Chem. Soc., Faraday Trans. 2, 1976, 72 (0), 1574-1583.

(18) D'Anna, B.; Sellevåg, S. R.; Wirtz, K.; Nielsen, C. J., Photolysis Study of Perfluoro-2-methyl-3-pentanone under Natural Sunlight Conditions. Environ. Sci. Technol. 2005, 39 (22), 8708-8711.

(19) Madronich, S.; Flocke, S., The Role of Solar Radiation in Atmospheric Chemistry. In Environmental Photochemistry, Boule, P., Ed. Springer Berlin Heidelberg: Berlin, Heidelberg, 1999; pp 1-26.

(20) Sehested, J.; Ellermann, T.; Nielsen, O. J.; Wallington, T. J.; Hurley, M. D., UV Absorption Spectrum, and Kinetics and Mechanism of the Self Reaction of $\mathrm{CF}_{3} \mathrm{CF}_{2} \mathrm{O}_{2}$ Radicals in the Gas Phase at 295 K. Int. J. Chem. Kinet. 1993, 25 (9), 701-717.

(21) Wallington, T. J.; Hurley, M. D.; Schneider, W. F.; Sehested, J.; Nielsen, O. J., Atmospheric chemistry of trifluoromethoxy radicals: reaction with water. J. Phys. Chem. 1993, 97 (29), 7606-7611. Alcohols in the Atmosphere. J. Phys. Chem. A 2007, 111 (51), 13466-13471.

(23) Le Crâne, J.-P.; Villenave, E.; Hurley, M. D.; Wallington, T. J.; Ball, J. C., Atmospheric Chemistry of Propionaldehyde: Kinetics and Mechanisms of Reactions with $\mathrm{OH}$ Radicals and $\mathrm{Cl}$ Atoms, UV Spectrum, and Self-Reaction Kinetics of $\mathrm{CH}_{3} \mathrm{CH}_{2} \mathrm{C}(\mathrm{O}) \mathrm{O}_{2}$ Radicals at 298 K. J. Phys. Chem. A 2005, 109 (51), 11837-11850. M. E.; Moortgat, G. K.; Zabel, F., Organic peroxy-radicals-kinetics, spectroscopy and tropospheric chemistry. Atmos. Environ. 1992, 26 (10), 1805-1961.

656 (25) Hodnebrog, Ø.; Etminan, M.; Fuglestvedt, J. S.; Marston, G.; Myhre, G.; Nielsen, 657 C. J.; Shine, K. P.; Wallington, T. J., Global warming potentials and radiative 658 efficiencies of halocarbons and related compounds: A comprehensive review. Rev. 659 Geophys. 2013, 51 (2), 300-378. 
(26) Rayne, S.; Forest, K., Prediction of the air-water partition coefficient for perfluoro-2-methyl-3-pentanone using high-level Gaussian-4 composite theoretical methods. J. Environ. Sci. Health., Part A 2014, 49 (11), 1228-1235.

(27) Hein, R.; Crutzen, P. J.; Heimann, M., An inverse modeling approach to investigate the global atmospheric methane cycle. Global Biogeochem. Cycles 1997, $11(1), 43-76$.

(28) Saiz-Lopez, A.; von Glasow, R., Reactive halogen chemistry in the troposphere. Chem. Soc. Rev. 2012, 41 (19), 6448-6472.

(29) Monks, P. S.; Granier, C.; Fuzzi, S.; Stohl, A.; Williams, M. L.; Akimoto, H.; Amann, M.; Baklanov, A.; Baltensperger, U.; Bey, I.; Blake, N.; Blake, R. S.; Carslaw, K.; Cooper, O. R.; Dentener, F.; Fowler, D.; Fragkou, E.; Frost, G. J.; Generoso, S.; Ginoux, P.; Grewe, V.; Guenther, A.; Hansson, H. C.; Henne, S.; Hjorth, J.; Hofzumahaus, A.; Huntrieser, H.; Isaksen, I. S. A.; Jenkin, M. E.; Kaiser, J.; Kanakidou, M.; Klimont, Z.; Kulmala, M.; Laj, P.; Lawrence, M. G.; Lee, J. D.; Liousse, C.; Maione, M.; McFiggans, G.; Metzger, A.; Mieville, A.; Moussiopoulos, N.; Orlando, J. J.; O'Dowd, C. D.; Palmer, P. I.; Parrish, D. D.; Petzold, A.; Platt, U.; Pöschl, U.; Prévôt, A. S. H.; Reeves, C. E.; Reimann, S.; Rudich, Y.; Sellegri, K.; Steinbrecher, R.; Simpson, D.; ten Brink, H.; Theloke, J.; van der Werf, G. R.; Vautard, R.; Vestreng, V.; Vlachokostas, C.; von Glasow, R., Atmospheric composition change - global and regional air quality. Atmos. Environ. 2009, 43 (33), 5268-5350.

(30) Kwok, E. S. C.; Atkinson, R., Estimation of hydroxyl radical reaction rate constants for gas-phase organic compounds using a structure-reactivity relationship: An update. Atmos. Environ. 1995, 29 (14), 1685-1695.

(31) Ren, Y.; Wang, J.; Grosselin, B.; Daële, V.; Mellouki, A., Kinetic and product studies of $\mathrm{Cl}$ atoms reactions with a series of branched Ketones. J. Environ. Sci. 2018, $71,271-282$.

(32) Houde, M.; Martin, J. W.; Letcher, R. J.; Solomon, K. R.; Muir, D. C. G., Biological Monitoring of Polyfluoroalkyl Substances: A Review. Environ. Sci. Technol. 2006, 40 (11), 3463-3473.

(33) Hanson, D. R.; Ravishankara, A. R., The loss of $\mathrm{CF}_{2} \mathrm{O}$ on Ice, Nat, and Sulfuricacid-solutions. Geophys. Res. Lett. 1991, 18 (9), 1699-1701.

(34) Nolle, A.; Krumscheid, C.; Heydtmann, H., Determination of quantum yields in the UV photolysis of $\mathrm{COF}_{2}$ and COFCl. Chem. Phys. Lett. 1999, 299 (6), 561-565.

(35) WMO (World Meteorological Organization) Scientific Assessment of Ozone Depletion: 2010, Global Ozone Research and Monitoring Project-Report; Switzerland, Geneva, 2011; p 516

(36) Jaegle, L.; Jacob, D. J.; Brune, W. H.; Wennberg, P. O., Chemistry of $\mathrm{HO}_{\mathrm{x}}$ radicals in the upper troposphere. Atmos. Environ. 2001, 35 (3), 469-489. 
700 Table 1. Experimental conditions and obtained results for the photolysis of perfluoro701 2-methyl-3-pentanone (PF-2M3P), perfluoro-3-methyl-2-butanone (PF-3M2B) and 2702 methyl-3-pentanone (2M3P).

\begin{tabular}{|c|c|c|c|c|c|c|}
\hline \multirow[b]{2}{*}{$\left(10^{13}\right.$ molecule $\left.\mathrm{cm}^{-3}\right)$} & \multirow{2}{*}{$\begin{array}{c}J_{\mathrm{NO} 2} \\
\left(10^{-3} \mathrm{~s}^{-1}\right)\end{array}$} & \multirow{2}{*}{$\begin{array}{c}\text { Photolysis } \\
\text { loss } \\
(\%)\end{array}$} & \multirow{2}{*}{$\begin{array}{l}\text { Irradiation } \\
\text { period } \\
\text { (h:mm) }\end{array}$} & \multicolumn{3}{|c|}{$\begin{array}{c}J \\
\left(10^{-6} \mathrm{~s}^{-1}\right)\end{array}$} \\
\hline & & & & FT-IR & $\begin{array}{c}\text { GC-MS } / \\
\text { PTR-TOF-MS }^{\mathrm{c}}\end{array}$ & $\operatorname{Rec}^{\mathrm{a}}$ \\
\hline \multicolumn{7}{|c|}{$3.4 \mathrm{~m}^{3}$ outdoor chamber } \\
\hline 18 & $4.4 \pm 1.1$ & 3.7 & $4: 23$ & $2.3 \pm 0.2$ & - & $2.3 \pm 0.4$ \\
\hline 18 & $4.9 \pm 0.9$ & 3.7 & $4: 18$ & $2.8 \pm 0.2$ & - & $2.8 \pm 0.4$ \\
\hline 27 & $4.4 \pm 1.5$ & 2.1 & $3: 39$ & $1.7 \pm 0.2$ & - & $1.7 \pm 0.4$ \\
\hline 8.9 & $5.5 \pm 0.6$ & 2.8 & $4: 13$ & $1.9 \pm 0.3$ & - & $1.9 \pm 0.6$ \\
\hline
\end{tabular}

PF-2M3P

HELIOS

\begin{tabular}{cccccccc} 
& 3.8 & $3.0 \pm 0.4$ & 1.7 & $4: 32$ & $1.1 \pm 0.1$ & $1.1 \pm 0.1^{\mathrm{b}}$ & $1.1 \pm 0.4$ \\
& 3.0 & $5.3 \pm 1.0$ & 7.7 & $5: 01$ & $3.8 \pm 0.3$ & $3.5 \pm 0.5^{\mathrm{b}}$ & $3.8 \pm 1.0$ \\
& 3.6 & $4.6 \pm 1.2$ & 6.1 & $7: 11$ & $2.2 \pm 0.3$ & $2.3 \pm 0.4^{\mathrm{b}}$ & $2.2 \pm 0.8$ \\
& 3.5 & $5.6 \pm 0.7$ & 7.4 & $7: 08$ & $3.7 \pm 0.5$ & $3.6 \pm 0.5^{\mathrm{b}}$ & $3.6 \pm 1.0$ \\
& 3.3 & $2.9 \pm 1.2$ & 5.7 & $6: 00$ & $1.6 \pm 0.7$ & $1.5 \pm 0.4^{\mathrm{b}}$ & $1.6 \pm 1.0$ \\
& 3.4 & $2.2 \pm 0.3$ & 3.9 & $5: 49$ & $1.2 \pm 0.2$ & $1.3 \pm 0.4^{\mathrm{b}}$ & $1.2 \pm 0.8$ \\
& 3.4 & $2.4 \pm 1.1$ & 3.9 & $6: 14$ & $1.5 \pm 0.2$ & $1.7 \pm 0.3^{\mathrm{b}}$ & $1.6 \pm 0.6$ \\
& 3.3 & $5.6 \pm 0.5$ & 6.3 & $5: 26$ & $2.7 \pm 0.7$ & $2.6 \pm 0.7^{\mathrm{b}}$ & $2.6 \pm 1.4$ \\
& 3.4 & $5.1 \pm 0.5$ & 5.3 & $6: 01$ & $2.1 \pm 0.7$ & $2.0 \pm 0.4^{\mathrm{b}}$ & $2.0 \pm 1.0$ \\
& 3.4 & $5.1 \pm 0.7$ & 4.8 & $4: 58$ & $2.0 \pm 0.6$ & $2.0 \pm 0.4^{\mathrm{b}}$ & $2.0 \pm 1.2$ \\
& & & & & & \\
\hline \multirow{2}{*}{ PF-3M2B } & 1.5 & $4.2 \pm 1.8$ & 2.0 & $5: 07$ & 1.1 & - & \\
& 0.09 & $7.6 \pm 1.3$ & $<0.2 \%$ & $5: 30$ & $<1 \%$ & & \\
& 0.05 & $7.7 \pm 1.4$ & $<0.2 \%$ & $5: 17$ & $<1 \%$ & - & $0.48 \pm 0.28$ \\
& 4.2 & $5.8 \pm 1.1$ & 1.3 & $5: 30$ & 0.67 & $0.28^{\mathrm{c}}$ & $0.98 \pm 0.50$
\end{tabular}

$703{ }^{a}$ Recommended value obtained from the weighted average of each individual 704 measurement: $J_{\mathrm{av}}=\left(\mathrm{w}_{1} J_{1}+\mathrm{w}_{2} J_{2}+\ldots\right) /\left(\mathrm{w}_{1}+\mathrm{w}_{2}+\ldots\right)$, where $\mathrm{w}=1 / \sigma^{2}$, etc. The error, is 705 given by: $2 \sigma_{\mathrm{av}}=\left(\sigma_{1}{ }^{2}+\sigma_{2}{ }^{2}+\ldots\right)^{0.5}$

$706{ }^{b}$ measured using GC-MS

$707{ }^{\mathrm{c}}$ measured using PTR-TOF-MS 
708 Table 2. Photolysis rate of perfluoro-2-methyl-3-pentanone (PF-2M3P), perfluoro-3-methyl-2-butanone (PF-3M2B) and 2-methyl-3-

709 pentanone (2M3P) obtained in this work and compared to the reported data from the literature.

710

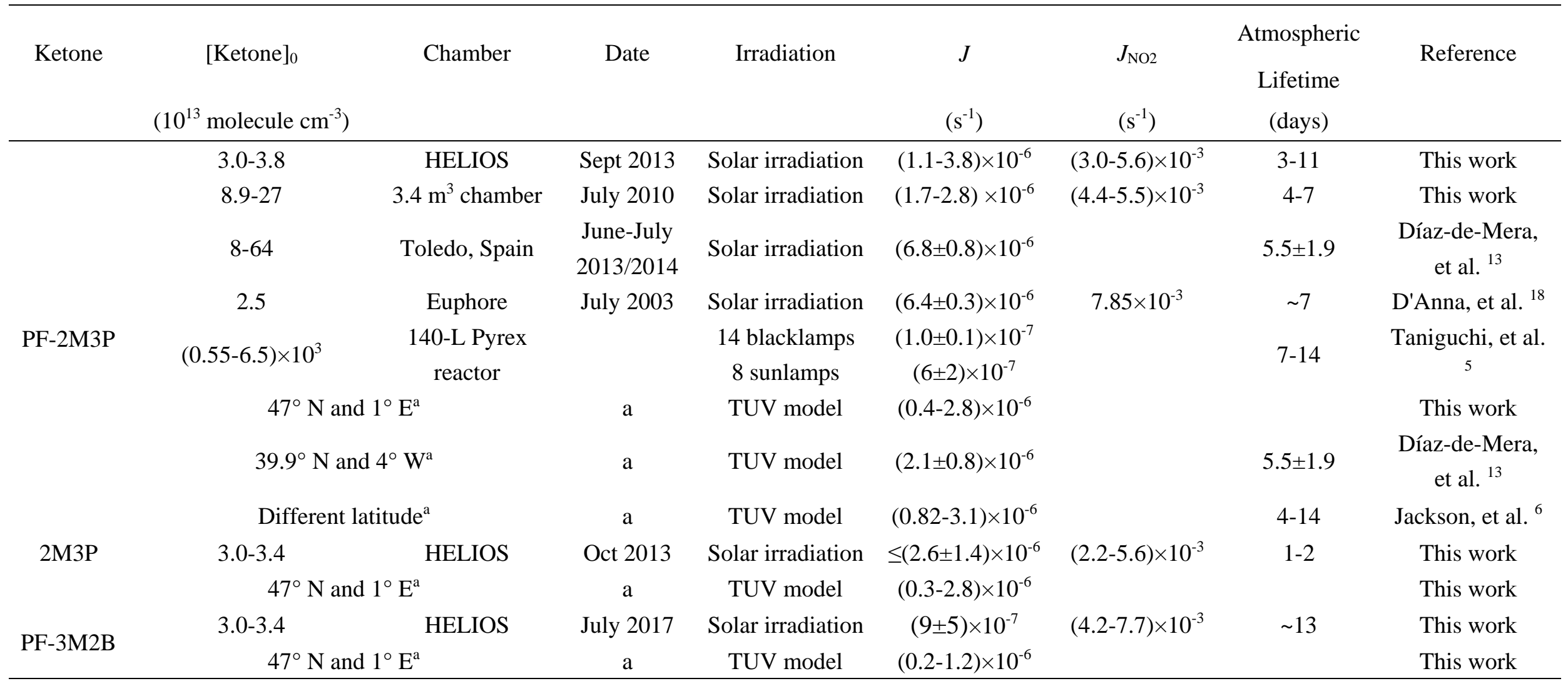

711 a yearly average; 


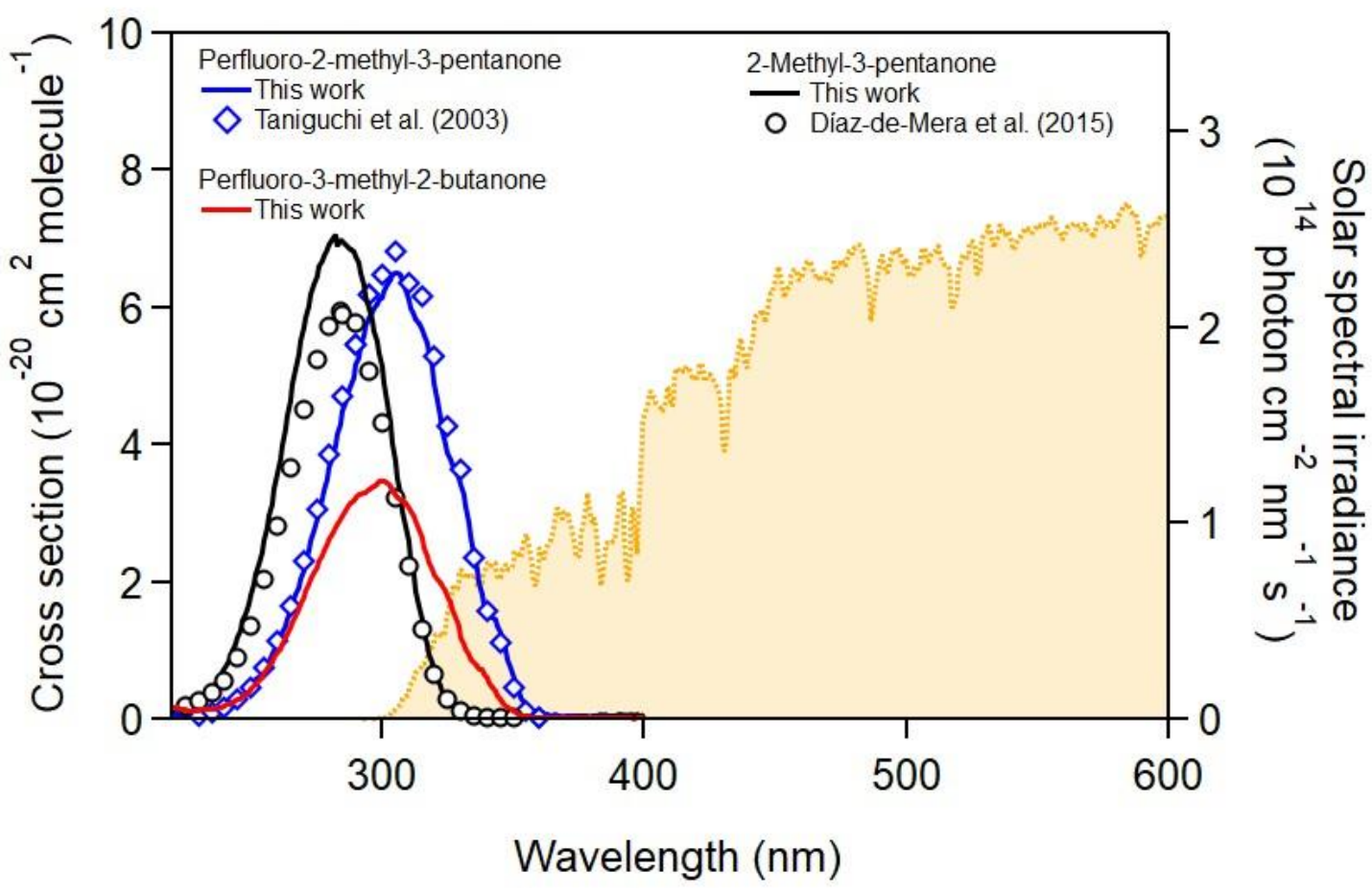

Figure 1. UV absorption spectra of perfluoro-2-methyl-3-pentanone (PF-2M3P), perfluoro-3-methyl-2-butanone (PF-3M2B) and 2-methyl-3-pentanone (2M3P) and compared with those from literature. The shaded area in yellow represents the solar spectral irradiance measured inside HELIOS (13:00 local time, 27 September 2013).

The figure 1 has been replaced 


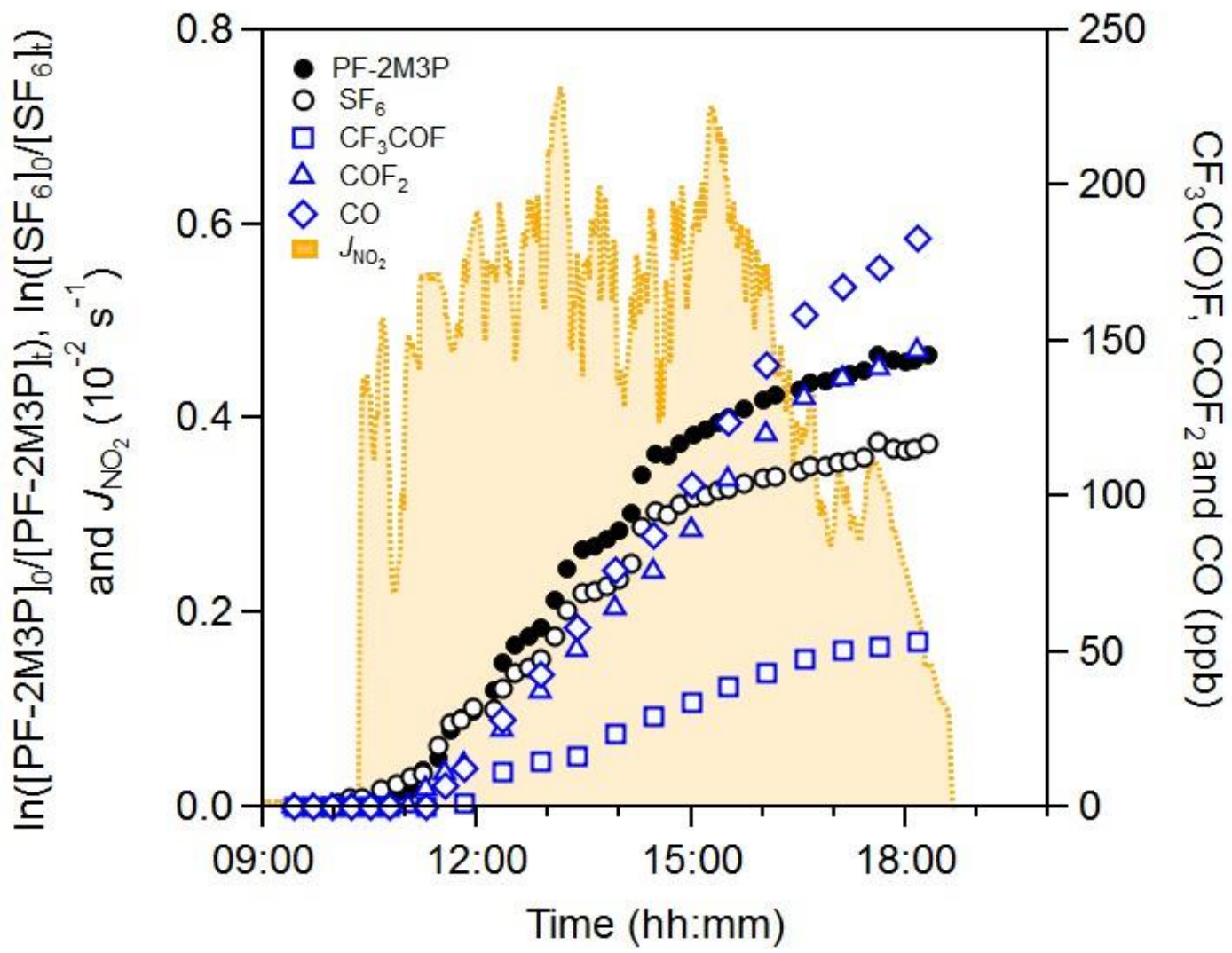

Figure 2. Perfluoro-2-methyl-3-pentanone $(\mathrm{PF}-2 \mathrm{M} 3 \mathrm{P})$ and its products during the photolysis experiment under natural irradiation in HELIOS (27 September 2013). 


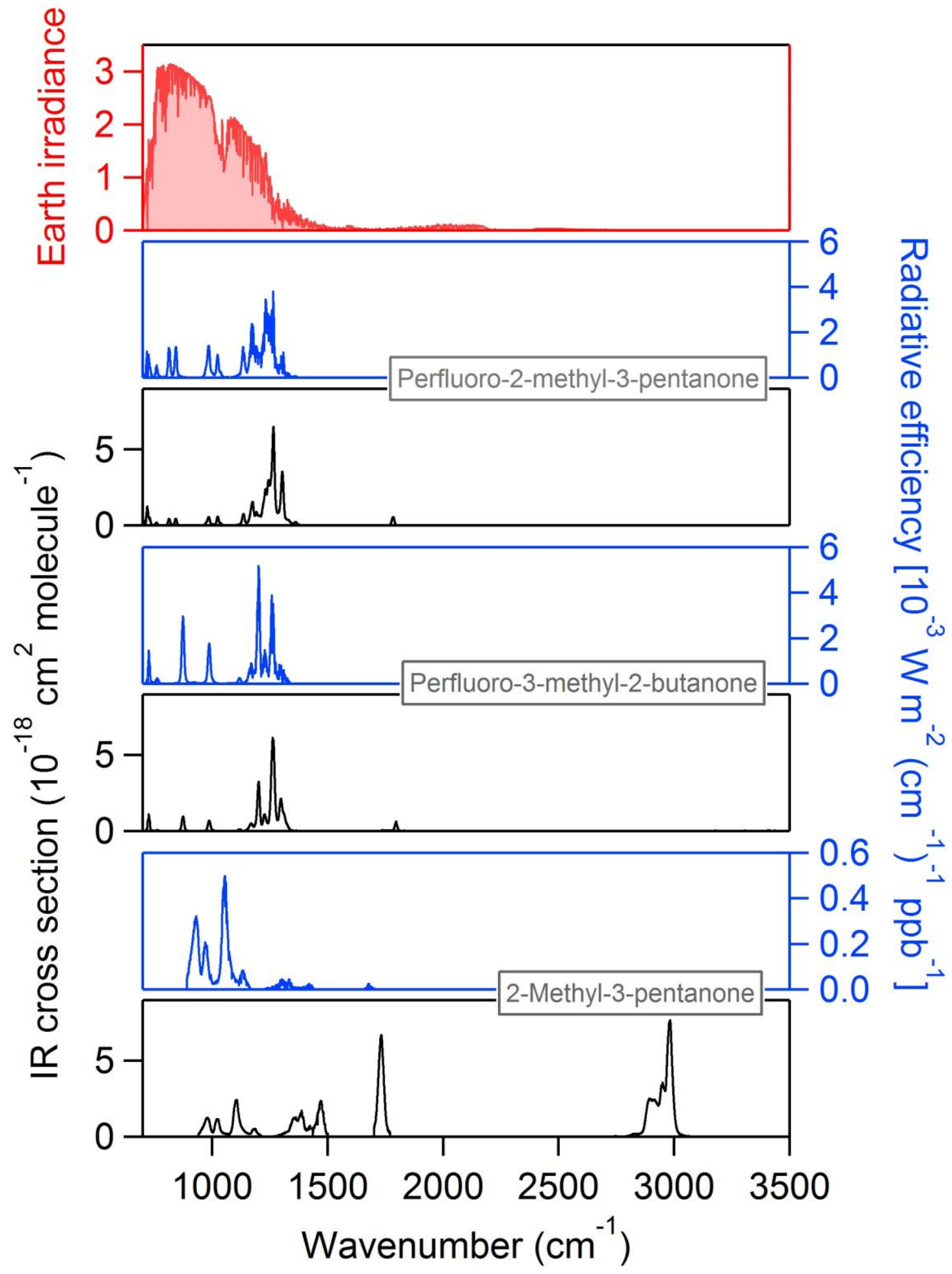

Figure 3. Infrared absorption of perfluoro-2-methyl-3-pentanone, perfluoro-3-methyl-

2-butanone and 2-methyl-3-pentanone and their contributions to the radiative efficiency. Earth's irradiance spectrum (top panel) is reported by Hodnebrog, et al. ${ }^{25}$ (in units of $\left.10^{-3} \mathrm{~W} \mathrm{~m}^{-2}\left(\mathrm{~cm}^{-1}\right)^{-1} \mathrm{ppb}^{-1}\left(10^{-18} \mathrm{~cm}^{2} \text { molecule }\right)^{-1}\right)$. The infrared absorption spectra measured in this work are showed in black, lower panel (in units of $10^{-18} \mathrm{~cm}^{2}$ molecule ${ }^{1}$, base e) and the radiative efficiency spectra are displayed in blue, upper panel (in units of $\left.\mathrm{W} \mathrm{m} \mathrm{m}^{-2}\left(\mathrm{~cm}^{-1}\right)^{-1} \mathrm{ppb}^{-1}\right)$. 